\title{
Removal of Hexavalent Chromium from Synthetic Wastewater Using Alginate Immobilized Cyanobacteria: Experiment and Mathematical Modeling
} \\ Edita Baltrènaite, ${ }^{3}$ and Susmita Dutta ${ }^{1, \star}$ \\ ${ }^{3}$ Institute of Environmental Protection, Vilnius Gediminas Technical University, Vilnius, Lithuania.
}

\begin{abstract}
The present study aims at removal of $\mathrm{Cr}(\mathrm{VI})$ using immobilized Limnococcus limneticus from synthetic wastewater. Four different methods were followed to immobilize test cyanobacterial strain onto calcium alginate bead and named as Cyanobacteria Immobilized Calcium alginate Bead $(C I C B)$. Based on the preparation method, they were termed as CICB1, CICB2, CICB3, and CICB4. Effect of input variables such as pH (5-11) and concentrations of sodium alginate $(20-40 \mathrm{~g} / \mathrm{L})$, calcium chloride $(14.7-44.1 \mathrm{~g} / \mathrm{L})$, and amount of algal dosage $(0.957-2.871 \mathrm{~g} / \mathrm{L})$ on the efficacy of beads in removal of $\mathrm{Cr}(\mathrm{VI})$ were examined. Comparative study showed that $C I C B 1$ was least efficient and maximum removal was obtained with $C I C B 2$, in which maximum cyanobacterial biomass was used. The effect of initial concentration (IC) of $\mathrm{Cr}(\mathrm{VI})$ on removal was studied using both $C I C B 3$ and $C I C B 4$ individually. The removal gradually decreased with increase in $\mathrm{IC}$ of $\mathrm{Cr}(\mathrm{VI}) \mathrm{for}$ both the beads. Scanning electron microscopy, energy dispersive spectroscopy, and Fourier transform infrared studies of CICB3 and CICB4 were done. To understand the molecular transport mechanism of Cr(VI) within the solution, mesoscale simulations using computational fluid dynamics were used for predicting the removal of hexavalent chromium.
\end{abstract}

Keywords: computational fluid dynamics; cyanobacteria; hexavalent chromium; immobilization; mathematical modeling

\section{AU7 Introduction}

AU8 HE ADVANCEMENT IN industrialization, increase in human population, and practices of agricultural activities have intensified the environmental pollution, and affect mainly the ecosystem with the accumulation of different pollutants such as dyes, pesticides, nuclear waste, organic chemicals, and potentially toxic elements (Papageorgiou et al., 2008). Water pollution in presence of potentially toxic elements causes a major threat to living organisms due to their recalcitrant and nonbiodegradable nature. After discharge to natural water bodies, potentially toxic elements directly affect the aquatic biota. The potentially toxic elements are present in different chemical states in the environment and eventually, accumulated in the food chain. Due to intensive industrial development and urbanization, the

AU6 * Corresponding author: Department of Chemical Engineering National Institute of Technology Durgapur, Durgapur 713209, West Bengal, India. Phone: +91 9434788120; Fax: +91-343-2547375; E-mail: susmita_che@yahoo.com noosphere receives high load of potentially toxic elements, which further results in the increase of contamination footprint (Baltrenaite et al., 2018). Although trace amount of these metals is necessary for growth, depending on the different chemical forms and exposure level, potentially toxic elements cause serious health hazards to human beings due to their carcinogenic and mutagenic nature (Sen et al., 2017). The presence of chromium in the water has been found as one of the major concerns due to its abundant use in the industrial sector. Chromium toxicity largely depends on its oxidation state, which varies in the range of -2 to +6 , in which trivalent (III) and hexavalent (VI) forms are the most stable forms (Allway and Ayres, 1997; Prabhakaran et al., \AU9 2019). Hexavalent chromium $[\mathrm{Cr}(\mathrm{VI})]$ is near about 300 times more toxic due to its mutagenic, teratogenic, and carcinogenic nature (Sen et al., 2017). The details of the chromium compounds and their toxicity were described by Gad (1989). In a review article, Kumar et al. (2015) showed that most of the studies on removal of chromium were based on hexavalent chromium. While $\mathrm{Cr}$ (III) may be used as an essential nutrients for some animal and plants, $\mathrm{Cr}(\mathrm{VI})$ is 
carcinogenic in nature. Thus, most of the researchers are interested in removal of $\mathrm{Cr}(\mathrm{VI})$ or reduction of it into $\mathrm{Cr}(\mathrm{III})$ (Ma et al., 2019). The sources of $\mathrm{Cr}$ include effluents from different industries such as dyeing, paint, wood processing, mining, metal cleaning, leather tanning, electroplating, and textile industries. As for example, Chhikara and Dhankhar (2008) reported the concentration of $\mathrm{Cr}(\mathrm{VI})$ in the electroplating industry effluent as $117 \mathrm{mg} / \mathrm{L}$. According to WHO guidelines, the extreme allowable limit of $\mathrm{Cr}(\mathrm{VI})$ in drinking water is $0.05 \mathrm{mg} / \mathrm{L}$, whereas EPA limits the total $\mathrm{Cr}$ level in drinking water to $100 \mu \mathrm{g} / \mathrm{L}$ (Gupta and Rastogi, 2009). Thus, proper treatment of $\mathrm{Cr}$ laden wastewater is mandatory to reduce its concentration below the permissible limit.

Several research groups used several techniques for removal of $\mathrm{Cr}$ from wastewater over last few decades. Among them, the most popular and conventional techniques are membrane separation, solvent extraction, chemical precipitation, ion exchange (Ahalya et al., 2003; Ahluwalia and Goyal, 2007; Mukherjee et al., 2013). Usage of biochar in removal of pollutants may be an alternative method (Glaser et al., 2017). However, the limitations of using these processes are high chemical or energy requirements, high cost of operation, and the formation of secondary pollutants. Further, the efficiency turns out to be very low when the $\mathrm{Cr}$ concentration in the solution is below $100 \mathrm{mg} / \mathrm{L}$ (Anjana et al., 2007). As a polishing step, researches are now tending toward biological treatment process that has gained a great attention to treat the wastewater in an efficient manner due to its numerous benefits over traditional conventional techniques. Removal of pollutants through bioremediants is a two-step process, biosorption and bioaccumulation. In biosorption, the uptake of pollutants occurs only in the cell wall and considered as a metabolism independent process, whereas, the intracellular uptake of pollutants takes place in bioaccumulation, which is a metabolically active process and restricted to living cells only (Dutta et al., 2016; Hu et al. 2019). The main advantages of biological removal over any other methods are low cost of operation, environment friendly nature, and high effectiveness in low metal concentration solution. Microorganism such as bacteria, fungi, yeasts, and so on are capable of removing pollutants from wastewater and polluted air (Baltrenas et al., 2016), but cyanobacteria have some additional advantages over others due to their higher surface area and mucilage volume with better binding affinity and requirements of simple nutrients (Sen et al., 2017). Several functional groups such as carboxyl, sulfate, amino, and amido present in algal or cyanobacterial cell attract the potentially toxic ions and quarantine within the cell (Bayramoğlu et al., 2006). Living, dead, and immobilized biomass of cyanobacteria can effectively be used in remediation process (Kumar et al., 2015).

Literature review shows that immobilized cell systems have several advantages such as easy separation of cells, provision of getting high cell concentration, suitable microenvironmental conditions, and elimination of cell washout problem at high dilution rates and improve chemical stability (Hu et al., 2016, 2017). Immobilization on some suitable matrix such as a form of bead has been proved to be useful to combat pollution due to its porous characteristics, rigidity, and higher mechanical strength. Further, through desorption, the metal can be recovered from the loaded beads which minimizes the potential of environmental contamination
(Bayramoğlu et al., 2006). Alginate, being commercially available as sodium salt of alginic acid at low cost, may be converted into a hydrogel via cross-linking with divalent calcium ions, where each divalent metal ion binds to two carboxyl groups as adjacent alginate molecules (Szekalska et al., 2016). As a skeletal component of marine algae, it has the property of being strong and at the same time flexible (Chatterjee et al., 2015). Some advantages of alginate beads are biodegradability, hydrophilicity, presence of carboxyl groups, and natural origin (Eroglu et al., 2015). Alginate has also been used for many biomedical applications due to its biocompatibility, low toxicity, relatively low cost, and mild gelation by the addition of divalent cations such as $\mathrm{Ca}^{2+}$. Due to such advantages, Ca-alginate is used as matrix for immobilization of bacterial cells, enzymes, and so on (Chatterjee et al., 2015; Ontañon et al., 2017). Again, the removal operation in a continuous packed bed reactor using microorganism immobilized calcium alginate bead as packing material would be a better approach to treat the wastewater effectively (Migahed et al., 2017). Several researchers used microorganism immobilized calcium alginate bead to remove heavy metals from wastewater (Cataldo et al., 2016; Wang et al., 2016, 2017). In a review article, De-Bashan and Bashan (2010) illustrated the synergistic effect of microalgae and calcium alginate. They showed that immobilization of microalgae in alginate beads had significantly increased the chlorophyll, carotenoids, dry weight, and lipid contents during the stationary and resting growth phases, compared to free-living cells. Further, photosynthesis had also been enhanced compared to free cells (De-Basan and Basan, 2010). Thus, the practical application of cyanobacteria immobilized calcium alginate bead $(C I C B)$ for the removal of $\mathrm{Cr}(\mathrm{VI})$ can be considered as a promising technique. Although there are several advantages of using Ca-alginate as immobilization matrix for microorganisms or enzymes, the usage of immobilized beads instead of free-living strain increases the cost of chemical for immobilization. It is found from the literature that under metal stressed condition, algae and/or cyanobacteria can accumulate higher lipid content and from the extracted lipid, biodiesel can be produced through transesterification (Markou and Nerantzis, 2013). Apart from lipid, other biomolecules such as protein and carbohydrate of biomass can be used for production of other value added products (Upendar et al., 2018). For free cyanobacterial cell, these value added products can be extracted easily from the biomass after the removal of pollutants, while the extraction of such products from immobilized cells is a technically challenged task. Further, the increase in mass transfer resistance and thereby, reduction in rate of metal uptake owing to immobilization of cells is an added disadvantage of such process. Keeping all these aspects in consideration, a comprehensive study comprising of preparation of immobilized cell system, characterization, kinetic study, and state-space representation using computational fluid dynamics (CFD) modeling to predict removal of $\mathrm{Cr}(\mathrm{VI})$, which has hardly been seen in literature, has been reported in the present article. Many researchers have studied the removal of $\mathrm{Cr}(\mathrm{VI})$ using algal biomass, but the implementation of COMSOL Multiphysics to predict the concentration at different time is quite terse. The present study highlights the removal of $\mathrm{Cr}(\mathrm{VI})$ from synthetic wastewater by Limnococcus limneticus, a cyanobacterial species, immobilized on calcium alginate 
following the four different methods. The effects of initial concentration (IC) of calcium chloride, sodium alginate, $\mathrm{pH}$, and biomass on removal of $\mathrm{Cr}(\mathrm{VI})$ were studied and the optimum values of these parameters were determined. Finally, state-space modeling has been used to predict the removal of $\mathrm{Cr}(\mathrm{VI})$.

\section{Experimental Protocols}

All the chemicals used in the present study were of Analytical Reagent grade and purchased from Merck, India. All the experiments were performed in triplicate and the mean data with standard deviation values were reported.

\section{Collection, identification, and culture of cyanobacterial strain}

The test strain was collected from the East Kolkata Wetland (EKW), a Ramsar Site as per 2002 convention, consisting of multifunctional wetland ecosystem. It comprises of sewage fed fisheries and small agricultural plots. The EKW nurtures the world's largest wastewater fed aquaculture system. Thus the microalgal strains obtained from such wastewater are resistant to pollutants (Sen et al., 2018). The details of collection, separation, and identification were reported by Sen et al. (2018). The strain was identified as L. limneticus. Finally, the identified strain was grown in pure sterile BG-11 media for laboratory culture inside an algal incubator maintained at temperature of $25^{\circ} \mathrm{C} \pm 2^{\circ} \mathrm{C}$ with light/dark cycle $(16 \mathrm{~h} / 8 \mathrm{~h})$ with light intensity of 2,500 Lux. Subcultures were maintained for every 15 days.

\section{Immobilization of cyanobacteria in calcium alginate bead}

Calcium alginate was selected as organic matrix for immobilization of cyanobacterial biomass. When sodium alginate is added to the aqueous solution of calcium salt, the calcium ions replace sodium ions and form insoluble calcium alginate compound. Four different methods were followed to immobilize test cyanobacterial strain onto calcium alginate bead.

\section{Without BG 11 medium}

The well-grown culture obtained after 15 days was used for the immobilization on calcium alginate bead. Specific volume $(100 \mathrm{~mL})$ of cyanobacterial culture was harvested by centrifugation at $5,000 \mathrm{rpm}$ for $15 \mathrm{~min}$. Sodium alginate solution was prepared by dissolving definite amount of sodium alginate in $100 \mathrm{~mL}$ of distilled water. Cell residue was mixed with $20 \mathrm{~mL}$ of autoclaved solution of sodium alginate. Later on, calcium chloride solution was prepared by dissolving requisite amount of $\mathrm{CaCl}_{2} \cdot 2 \mathrm{H}_{2} \mathrm{O}$ in $1,000 \mathrm{~mL}$ of distilled water. The solution was then autoclaved. The cyanobacterial mixture was added drop by drop into $\mathrm{CaCl}_{2} \cdot 2 \mathrm{H}_{2} \mathrm{O}$ solution using micro pipette at $4^{\circ} \mathrm{C}$ to form uniform size spherical beads ( $\sim 3 \mathrm{~mm}$ diameter) in the laminar chamber. The cyanobacterial beads were rinsed by sterile distilled water.

To get optimum condition for immobilization, the following experiment was carried out. First, the concentrations of sodium alginate $(20,30$, and $40 \mathrm{~g} / \mathrm{L})$, calcium chloride $(14.7,29.4$, and $44.1 \mathrm{~g} / \mathrm{L})$, algal biomass $(0.957,1.914$, and $2.871 \mathrm{~g} / \mathrm{L})$, and $\mathrm{pH}(5,7,9$, and 11$)$ were varied individually. The ability to remove $\mathrm{Cr}(\mathrm{VI})$ was tested for beads prepared at each experimental condition and the corresponding condition at which maximum removal was obtained was considered as optimum. The beads produced at optimum condition following such method were termed as CICB1.

\section{With BG-11 medium}

In the next study, a new approach was tested for immobilization of cyanobacterial strain in calcium alginate bead. Two different weights of biomass such as 2.87 and $7 \mathrm{~g} / \mathrm{L}$ were used separately. Initially, to confirm higher removal of $\mathrm{Cr}(\mathrm{VI})$, higher algal biomass $(7 \mathrm{~g} / \mathrm{L})$ was used. Later, the concentration of algal biomass $(2.87 \mathrm{~g} / \mathrm{L})$, which was found to be optimum during preparation of $C I C B 1$, was chosen for preparation of immobilized cyanobacterial strain having lower concentration of biomass. Sodium alginate solution $(20 \mathrm{~g} / \mathrm{L})$ was prepared by dissolving $2 \mathrm{~g}$ sodium alginate in $100 \mathrm{~mL}$ of distilled water. Cell residue was mixed with $20 \mathrm{~mL}$ of autoclaved solution of $20 \mathrm{~g} / \mathrm{L}$ sodium alginate. Later, $40 \mathrm{~mL}$ sterile BG 11 medium was added to this mixture to yield a mixture of cyanobacterial suspension, sodium alginate, and BG-11 media. $\mathrm{CaCl}_{2} \cdot 2 \mathrm{H}_{2} \mathrm{O}(29.4 \mathrm{~g} / \mathrm{L})$ was dissolved in $1,000 \mathrm{~mL}$ of distilled water and the solution was then autoclaved. The cyanobacterial cells in the mixture of sodium alginate and BG-11 was then dropped into $29.4 \mathrm{~g} / \mathrm{L}$ $\mathrm{CaCl}_{2} \cdot 2 \mathrm{H}_{2} \mathrm{O}$ solution aseptically using micro pipette at $4{ }^{\circ} \mathrm{C}$ to form uniform-sized spherical beads ( $\sim 3 \mathrm{~mm}$ diameter). The algal beads were rinsed using sterile distilled water. The beads with higher algal biomass $(7 \mathrm{~g} / \mathrm{L})$ were termed as $C I C B 2$ and the beads with lower algal biomass $(2.87 \mathrm{~g} / \mathrm{L})$ were termed as $C I C B 3$. They were tested for $\mathrm{Cr}(\mathrm{VI})$ removal independently. In the fourth method, $2 \mathrm{~g}$ sodium alginate solution was dissolved in $100 \mathrm{~mL}$ of BG-11 media. The concentration of cyanobacterial biomass $(2.87 \mathrm{~g} / \mathrm{L})$, which was found to be optimum during preparation of $C I C B 1$ was chosen to be used in such method. Cell residue was mixed with $20 \mathrm{~mL}$ of autoclaved solution of $20 \mathrm{~g} / \mathrm{L}$ sodium alginate. Later, $40 \mathrm{~mL}$ sterile BG 11 medium was added in this mixture to yield a mixture of cyanobacterial cells, sodium-alginate and BG-11 media. The cyanobacterial mixture was then dropped into $29.4 \mathrm{~g} / \mathrm{L} \mathrm{CaCl}{ }_{2} \cdot 2 \mathrm{H}_{2} \mathrm{O}$ solution aseptically using micro pipette at $4^{\circ} \mathrm{C}$ to form uniform-sized spherical beads ( $\sim 3 \mathrm{~mm}$ of diameter). The cyanobacterial beads were rinsed using autoclaved distilled water. The beads produced following such method were termed as CICB4. To assess the role of cyanobacterial strain, control experiments were performed with the calcium alginate bead without cyanobacteria. The beads were prepared under identical conditions as mentioned above without immobilizing cyanobacteria. The glimpse of methods to prepare the alginate beads using different methods are shown in Table 1.

\section{Investigation of potential of beads for $\mathrm{Cr}(\mathrm{VI})$ removal}

Stock solution of $\mathrm{Cr}(\mathrm{VI})(100 \mathrm{mg} / \mathrm{L})$ was prepared by dissolving $0.1414 \mathrm{~g}$ of $\mathrm{K}_{2} \mathrm{Cr}_{2} \mathrm{O}_{7}$ in $500 \mathrm{~mL}$ distilled water. It was then diluted to $10 \mathrm{mg} / \mathrm{L}$ solution by adding requisite amount of distilled water. To study the efficacy of prepared beads, $50 \mathrm{~mL}$ of $10 \mathrm{mg} / \mathrm{L} \mathrm{Cr}(\mathrm{VI})$ solution was contacted with $5 \mathrm{~g}$ of beads, prepared by any of the above four methods, in $100 \mathrm{~mL}$ of Erlenmeyer flask. The flasks were kept in an algal incubator under specified input conditions and were occasionally shaken manually. For CICB1, the removal of 
Table 1. Methods of Preparation of Different Beads

\begin{tabular}{lccc}
\hline Types of bead & $\begin{array}{c}\text { Medium to prepare sodium } \\
\text { alginate solution }\end{array}$ & $\begin{array}{c}\text { Medium to prepare mixture of cell } \\
\text { suspension and sodium alginate }\end{array}$ & $\begin{array}{c}\text { Cyanobacterial } \\
\text { dose }(\mathrm{g} / \mathrm{L})\end{array}$ \\
\hline CICB 1 & Distilled water & Distilled water & 2.87 \\
$C I C B$ 2 & Distilled water & BG-11 & 7 \\
$C I C B$ B 3 Distilled water & BG-11 & BG-11 & 2.87 \\
$C I C B$ & BG-11 & 2.87 \\
\hline
\end{tabular}

$C I C B$, Cyanobacteria Immobilized Calcium alginate Bead.

$\mathrm{Cr}(\mathrm{VI})$ was achieved within $1 \mathrm{~h}$. Thus for $C I C B 1$, samples were collected after $1 \mathrm{~h}$. However, a distinct increase in removal was observed with $C I C B 2, C I C B 3$, and $C I C B 4$. Experiments were run for 20 days and the samples were collected. From the collected samples, the beads were separated from solution by filtration and the solution was analyzed for residual $\mathrm{Cr}(\mathrm{VI})$ concentration using Atomic Absorption Spectrophotometer (Perkin-Elmer PinAAcle 900T). To examine the efficacy of $C I C B$, removal of $\mathrm{Cr}(\mathrm{VI})$ using only alginate beads (abiotic control) and free cyanobacterial strain without immobilization (biotic control) were investigated under identical removal conditions.

\section{Characterization of immobilized bead}

SEM (scanning electron microscopy), EDS (energy dispersive spectroscopy), and FTIR (Fourier transform infrared) spectroscopy studies were performed to characterize the biosorbent with and without $\mathrm{Cr}$ loading conditions. SEM images of biosorbents, which were prepared following the same condition as that of $C I C B 3$ and $C I C B 4$ without using cyanobacterial cells, were taken using Scanning Electron Microscope (ZEISS) to acquire their topographical characteristics at desired magnification. Further, SEM images of $C I C B 3$ and $C I C B 4$ with and without $\mathrm{Cr}(\mathrm{VI})$ loading, were also taken. Analysis was done at working distance of $6 \mathrm{~mm}$ and acceleration voltage of $5 \mathrm{kV}$. EDS study (ZEISS) was performed to get elemental analysis of the $C I C B 3$ and $C I C B 4$ before and after treatment with $\mathrm{Cr}(\mathrm{VI})$. FTIR analyses of the samples were obtained using a Perkin-Elmer FTIR Spectrometer (IACS, Kolkata, India) for determination of functional groups with their stretching frequencies over the range of $400-4,000 \mathrm{~cm}^{-1}$ wavenumber.

The efficiency of the beads was estimated in terms of its stability and strength. To study the stability of the beads, they were kept under distilled water taken in a beaker, and the beaker was kept inside a refrigerator. Beads were collected after 1 week interval and the efficacies of beads in removal of $\mathrm{Cr}(\mathrm{VI})$ were judged. The strength of the beads was measured in terms of its hardness. To measure the hardness of the beads, compression test was done with increasing load over a bead sample and measured the stress of sample.

\section{Variation of removal of $\mathrm{Cr}(\mathrm{VI})$ with time for different IC of $\mathrm{Cr}(\mathrm{VI})$}

$\mathrm{Cr}(\mathrm{VI})$ solution $(10 \mathrm{mg} / \mathrm{L})$ was contacted with $5 \mathrm{~g}$ of each of $C I C B 2, C I C B 3$, and $C I C B 4$ individually for 14 days to compare the efficiency of these beads. The volume of solution was kept $50 \mathrm{~mL}$. After 14 days, the solution was analyzed for residual $\mathrm{Cr}(\mathrm{VI})$ concentrations.
To observe the variation of $\mathrm{Cr}(\mathrm{VI})$ removal with time, $C I C B 3$ and $C I C B 4$ were contacted with simulated solution of $\mathrm{Cr}(\mathrm{VI})$ for 20 days in a batch contactor. One input parameter such as IC $(5,10$, and $15 \mathrm{mg} / \mathrm{L})$ was varied. All the experiments were done in $250 \mathrm{~mL}$ of conical flask. The volume of solution and $\mathrm{pH}$ were kept $50 \mathrm{~mL}$ and 7 , respectively. Samples were collected after 2 days interval and analyzed for residual $\mathrm{Cr}(\mathrm{VI})$ concentrations. The algal incubator was maintained at temperature of $25^{\circ} \mathrm{C} \pm 2{ }^{\circ} \mathrm{C}$ with light/dark cycle $(16 \mathrm{~h} / 8 \mathrm{~h})$ with light intensity of $2,500 \mathrm{Lux}$.

\section{Mathematical modeling}

In the present study, a mathematical modeling using CFD has been implemented to assess the molecular transport mechanism of $\mathrm{Cr}(\mathrm{VI})$ within the solution. Model can predict the concentration profile of $\mathrm{Cr}(\mathrm{VI})$ with time, which can be validated with the experimental results. Normally, three basic conservation equations of mass, momentum, and energy conversation laws are considered for solving any practical problem. As the system is isothermal, no motion in the system makes the momentum and energy conversation laws undisturbed. So, a standard transient convective-diffusion mass transport equation is considered to study the experimental phenomena on removal of $\mathrm{Cr}(\mathrm{VI})$, and to solve such a phenomenon, the approach of CFD was used.

As the concentration changes with time, the unsteady state mass balance has been done here. The equation is represented as follows:

$$
\begin{gathered}
\frac{\partial C^{*}}{\partial t}+\nabla \cdot\left(U^{*} C^{*}\right)=\nabla \cdot\left(D^{*} \nabla \cdot C^{*}\right)+S^{*} \\
S^{*}=-k_{a d}\left(C^{*}-C_{e}\right)
\end{gathered}
$$

Accumulation term and convective mass transport term are the first and second terms, respectively, in the left hand side of Equation (1) while diffusive term and source term are in right hand side of Equation (1).

As, $U^{*}=0$ due to absence of agitation, Equation (1) reduces to:

$$
\frac{\partial C^{*}}{\partial t}=\nabla \cdot\left(D^{*} \nabla \cdot C^{*}\right)-k_{a d}\left(C^{*}-C_{e}\right)
$$

The suggested model was based on some assumptions which are given below:

(1) The adsorbent bed was considered as a bunch of particles having equal size with uniform porosity. 
(2) An adsorbent bed was considered settled at the bottom and the system was stationary throughout the process.

(3) Initially the adsorbent bed was free of $\mathrm{Cr}$.

(4) No convective mass transfer present in the system. Only mass transport resistance and biosorption resistance are present. Biosorption resistance was the dominant factor in this model.

(5) The entire system was temperature and pressure independent, that is, isothermal and isobaric.

(6) As convective velocity has been assumed as zero, there is no turbulence

First order bio-adsorption rate kinetics, boundary conditions, and fine mesh size were considered for developing and solving the model.

The values of $D^{*}$ and $k_{a d}$ were found by adjusting parameter method. Using the values of $D^{*}$ and $k_{a d}$, concentration profiles with respect to time would be obtained from the nonlinear Equation (3). Thus, minimum number of model parameters $\left(D^{*}\right.$ and $\left.k_{a d}\right)$, which are reliable and capable to explain the removal of $\mathrm{Cr}(\mathrm{VI})$ from the contaminant solution over a wide range of $\mathrm{IC}$ of $\mathrm{Cr}$, was used to verify experimental results. For the model implementation, the finite difference commercial solver COMSOL Multiphysics (version 4.3a; COMSOL, Inc., Burlington, MA) solves the partial differential equations.

\section{Statistical analysis}

To analyze the difference between the equality of variance and mean values for the removal of $\mathrm{Cr}(\mathrm{VI})$, a paired-samples $F$-test and $t$-test (two-tailed) was performed. Statistical analysis was done by varying the IC of $\mathrm{Cr}(\mathrm{VI})$ from 5 to $15 \mathrm{mg} / \mathrm{L}$, and the removal of $\mathrm{Cr}(\mathrm{VI})$ was analyzed for every 2 days. For statistical analysis, the confidence level was set as 0.05 and IBM SPSS Statistics 20.0 (IBM, Armonk, NY) was used.

\section{Results and Discussion}

\section{Growth study in normal BG-11 media}

The variation of dry biomass content with time is shown in

F1 Fig. 1 when L. limneticus has been grown in BG-11 medium. From Fig. 1, it is seen that the lag phase exists for the duration of 0-2 days. During lag phase, cyanobacteria synthesize new enzymes and orienting the metabolite pathway for adaptation to new environment. Thus, growth during such period is very less (Sen et al., 2017). Stationary phase starts after 14 days. In between, the log phase or exponential phase exists. Biomass has increased from $0.0408 \pm 0.002 \mathrm{~g} / \mathrm{L}$ to $0.4272 \pm 0.024 \mathrm{~g} / \mathrm{L}$ during $\log$ phase in the time course of 2-14 days. For the growth of cyanobacteria, some essential nutrients play a very important role. During log phase, the abundance of such essential nutrients facilitates the active growth of the strain, whereas after the active growth is over, lack of those nutrients causes no further growth of the strain (Sen et al., 2017).

\section{Characterization of immobilized bead}

SEM of blank Ca-alginate bead, cyanobacteria immobilized alginate beads, and cyanobacteria immobilized bead after the treatment with $\mathrm{Cr}(\mathrm{VI})$ for both $C I C B 3$ and $C I C B 4$

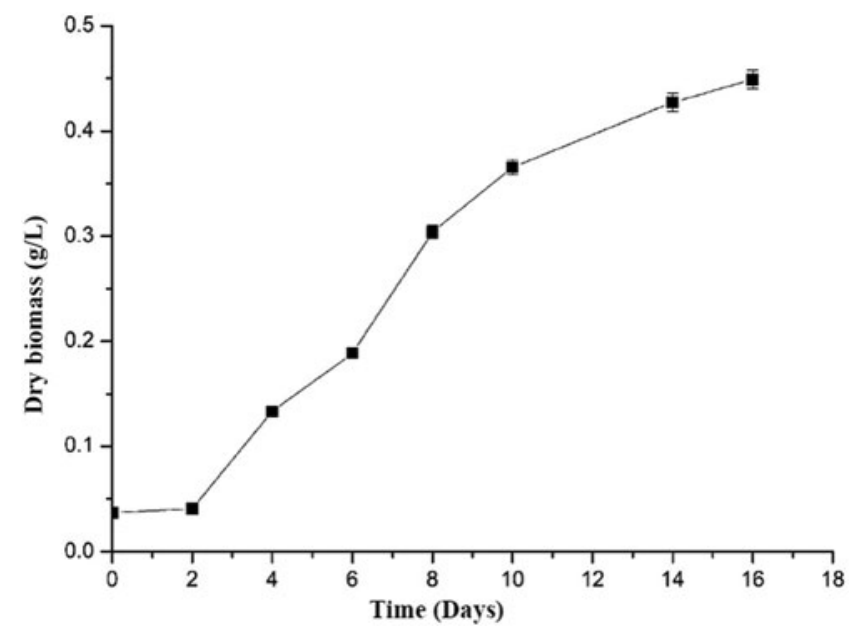

FIG. 1. Growth study of the cyanobacterial strain in normal BG-11 media.

have been done and the micrograms are shown in Fig. 2a-f, $<\mathrm{F} 2$ respectively. From Fig. $2 \mathrm{a}-\mathrm{f}$ distinct differences in surface structure have been seen. SEM image of Ca-alginate bead without cyanobacterial biomass shows polymeric bead-like structure, whereas after algal immobilization, a smoothening effect is seen and size has also been enlarged. After treatment with $\mathrm{Cr}(\mathrm{VI})$, the smoothening effect is even more, which indicates the binding of $\mathrm{Cr}(\mathrm{VI})$ onto the treated alginate beads. Such smoothness of the surface may be due to the binding of $\mathrm{Cr}(\mathrm{VI})$ onto the alginate beads that makes the surface less coarser than its original form. SEM studies were performed by several researchers during the removal of pollutants using alginate immobilized beads (Cataldo et al., 2016; Wang et al., 2016, 2017). Cataldo et al. (2016) showed that before treatment, the surface of the beads were smooth, whereas a shrinkage of the beads was observed at high metal ion concentration for the treated bead. Wang et al. (2016) observed from the SEM study that for the treated beads, the metal ions distributed homogeneously over the entire surface. In another study Wang et al. (2017) observed a pore-like structure of the beads after being contacted with metal ions. The EDS spectra of the four samples have been done. EDS spectra of untreated and treated $C I C B 3$ and $C I C B 4$ have been shown in Fig. $2 \mathrm{~g}-\mathrm{j}$, respectively. Tables 2 and 3 give a com- $4 \mathrm{~T} 2 \quad 4 \mathrm{~T} 3$ parative elemental analysis of the same samples. From Fig. $2 \mathrm{~g}-\mathrm{j}$ and Tables 2 and 3 , it is seen that the presence of $\mathrm{Cr}$ is found only in the treated algae immobilized alginate bead, whereas no trace of $\mathrm{Cr}$ has been found in the other two beads. The presence of $\mathrm{Cr}$ in the treated algae immobilized alginate bead confirms the binding of $\mathrm{Cr}(\mathrm{VI})$ onto the treated bead. Tables 4 and 5 represent the FTIR data of both CICB3 $<$ T4 4 T5 and $C I C B 4$ for blank beads, cyanobacteria immobilized beads, and immobilized beads after treatment with $\mathrm{Cr}(\mathrm{VI})$. Supplementary Figure S1a-f representing the FTIR spectra $\varangle$ SF1 of both $C I C B 3$ and $C I C B 4$ for blank beads, cyanobacteria immobilized beads, and immobilized beads after treatment with $\mathrm{Cr}(\mathrm{VI})$ are incorporated as "Supplementary Data." In case of blank $C I C B 3$, the main characteristics bonds are C-S and C-O-C, C-C and C-N, N-H (Bend), - $\mathrm{PH}$, and - $\mathrm{OH}$ at the corresponding wave number of $667,1,047,1,605,2,367$, and $3,742 \mathrm{~cm}^{-1}$. For immobilized $C I C B 3$ before treatment, the responsible bonds are $\mathrm{C}-\mathrm{S}$ and $\mathrm{C}-\mathrm{OH}, \mathrm{C}=\mathrm{O}$ and $\mathrm{C}==\mathrm{C}$, and 

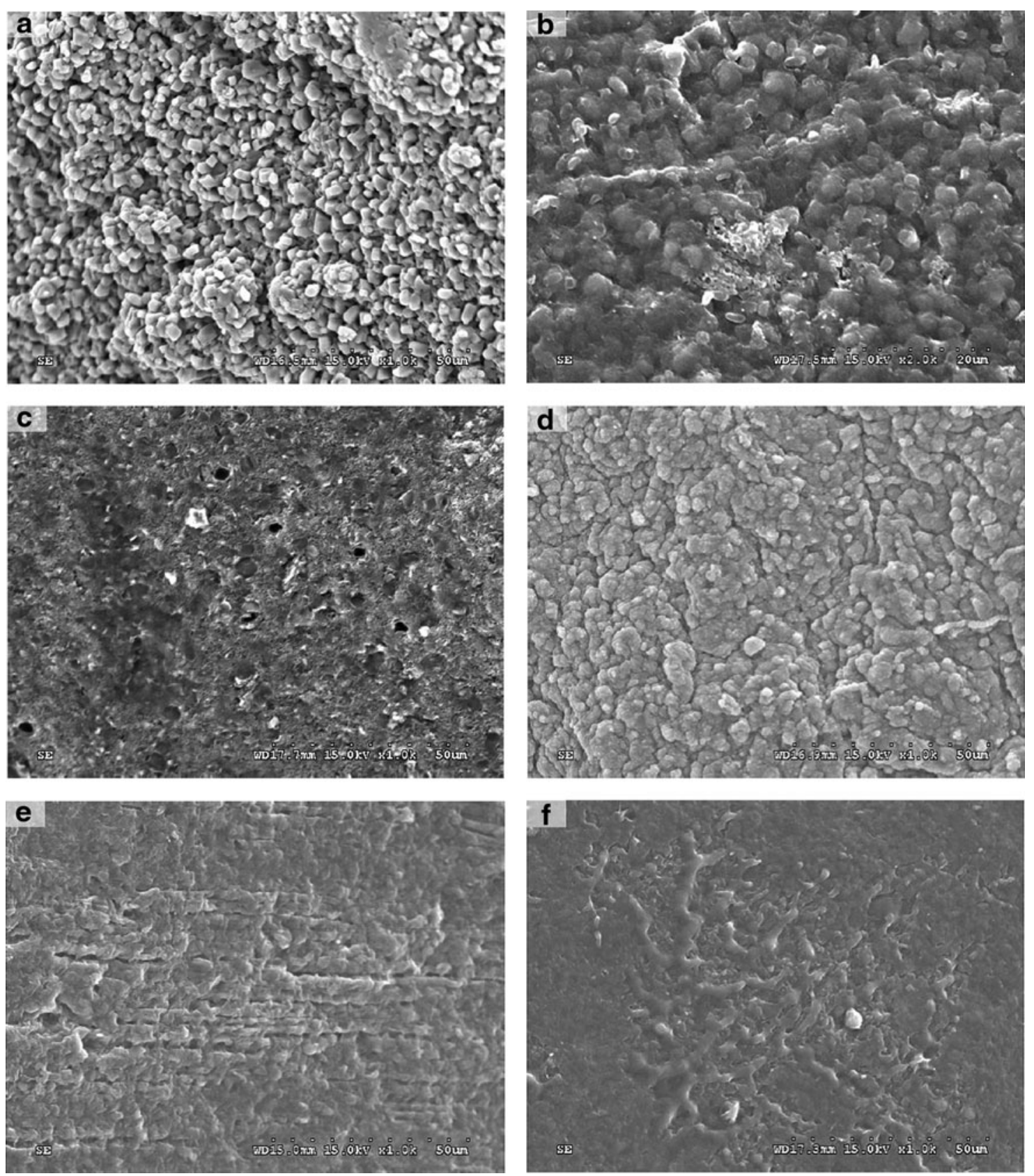

FIG. 2. (a-c) SEM images of blank Ca-alginate bead for $C I C B 3, C I C B 3$ before treatment with $\mathrm{Cr}(\mathrm{VI}), C I C B 3$ after treatment with $\mathrm{Cr}(\mathrm{VI})$; (d-f) SEM images of blank Ca-alginate bead for CICB4, CICB4 before treatment with Cr(VI), $C I C B 4$ after treatment with $\mathrm{Cr}(\mathrm{VI})$; $(\mathbf{g}, \mathbf{h})$ EDS spectra $C I C B 3$ before and after the treatment with $\mathrm{Cr}(\mathrm{VI}) ;(\mathbf{i}$, j) EDS spectra $C I C B 4$ before and after the treatment with $\mathrm{Cr}(\mathrm{VI}) . C I C B$, cyanobacteria immobilized calcium alginate bead; EDS, energy dispersive spectroscopy; SEM, scanning electron microscopy.

-PH at wavenumbers $667,1,633$, and $2,358 \mathrm{~cm}^{-1}$, respectively. While for treated bead, the bonds present are $\mathrm{C}-\mathrm{N}-\mathrm{C}$, $\mathrm{P}-\mathrm{O}-\mathrm{C}$, and $\mathrm{C}-\mathrm{C}, \mathrm{C}-\mathrm{N}$ and $-\mathrm{OH}, \mathrm{COO}-$, and $-\mathrm{NH}_{2}$ at 416 , $1,038,1,420,1,596$, and $3,399 \mathrm{~cm}^{-1}$ wavenumbers, respectively. Similarly for blank CICB4, the responsible functional groups are $\mathrm{C}-\mathrm{C}, \mathrm{C}-\mathrm{N}$ and $-\mathrm{OH}, \mathrm{NH}_{2},-\mathrm{PH}$, and $\mathrm{N}-\mathrm{H}$ at wavenumbers $1,020,1,420,1,596,2,367$, and $3,296 \mathrm{~cm}^{-1}$, respectively. For untreated $\mathrm{CICB} 4, \mathrm{C}-\mathrm{N}-\mathrm{C}, \mathrm{P}-\mathrm{O}-\mathrm{C},-\mathrm{OH}$, COO-, $-\mathrm{CH} 3$ and $-\mathrm{CH} 2$, and $-\mathrm{NH} 2$ bonds are responsible at wavenumbers $462,1,038,1,438,1,605,2,925$, and $3,389 \mathrm{~cm}^{-1}$. While for treated bead, the peak of 1,438 and
$3,389 \mathrm{~cm}^{-1}$ are shifted to 1,429 and $3,436 \mathrm{~cm}^{-1}$. Further, at wavenumbers $667,1,652$, and $2,367 \mathrm{~cm}^{-1}$, additional functional groups of C-N-C, COO-, $-\mathrm{CH}_{3}$, and $-\mathrm{CH}_{2}$ are appeared in treated bead. In a study of $\mathrm{Cd}(\mathrm{II})$ removal using immobilized Rhizomucor tauricus, Kumar et al. (2009) found that the responsible groups for cadmium removal are $-\mathrm{OH}$ and $-\mathrm{NH}$ stretching, $-\mathrm{CH}$ stretching, and $\mathrm{C}=\mathrm{O}$ groups. In another study on removal of heavy metal ions from drinking water by alginate-immobilized Chlorella sorokiniana, Petrovič and Simonič (2015) found the strongest absorption peak at $3,402 \mathrm{~cm}^{-1}$, which corresponds to the $-\mathrm{OH}$ stretching of 
g

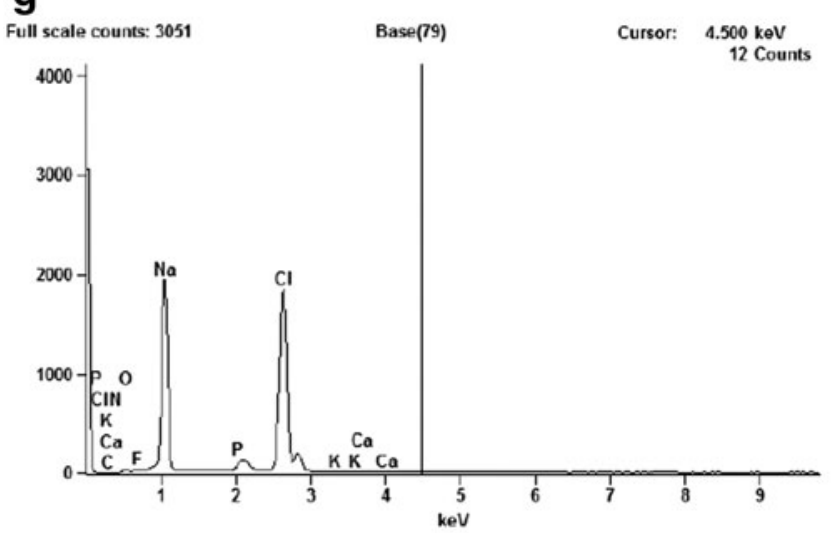

i

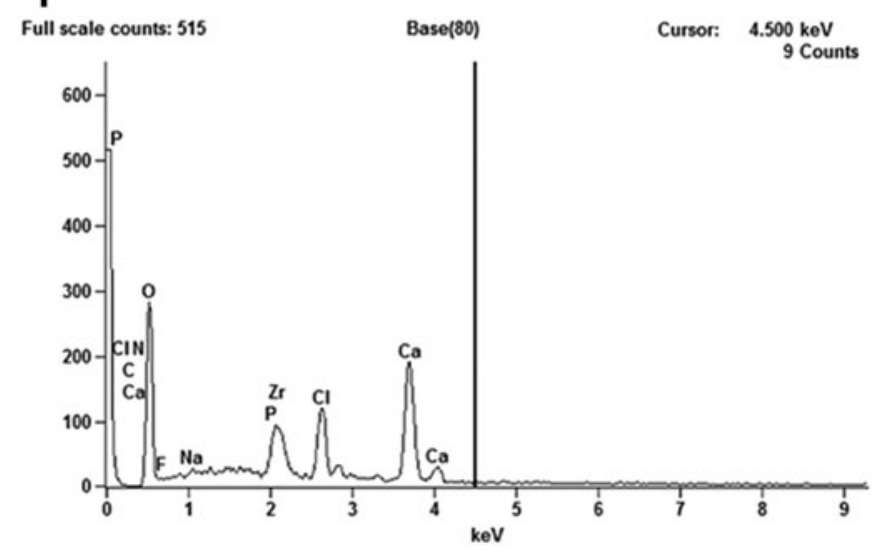

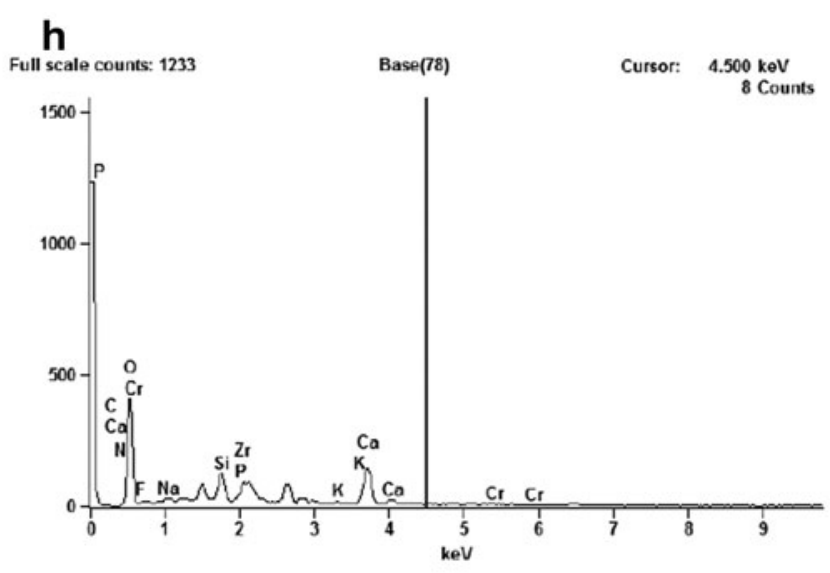
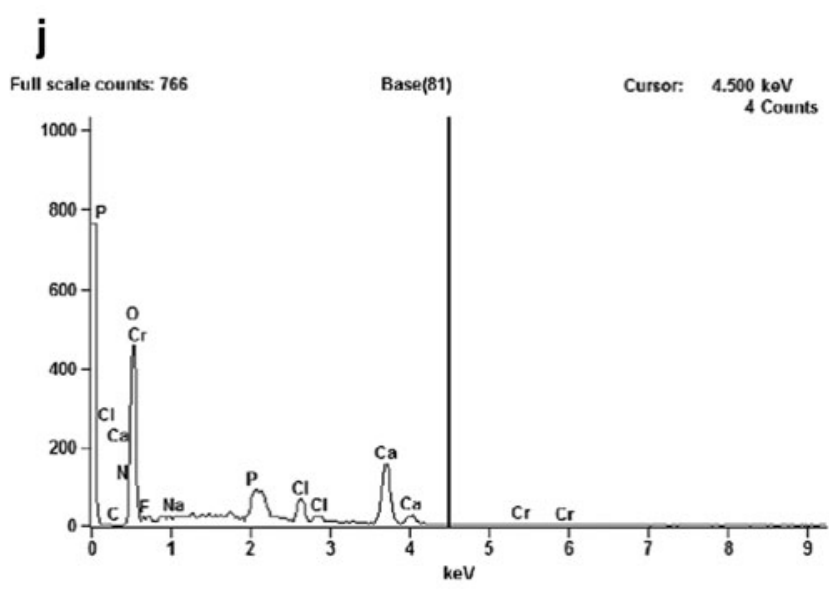

FIG. 2. (continued)

Table 2. Energy Dispersive Spectroscopy Analysis of (a) Cyanobacteria Immobilized Alginate Beads AND (B) CyanobaCteria ImMOBILIZED Bead of $C I C B 3$ After the Treatment with Cr(VI)

\begin{tabular}{|c|c|c|c|}
\hline \multicolumn{2}{|l|}{$\begin{array}{l}\text { CICB } 3 \text { before } \\
\text { experiment }(a)\end{array}$} & \multicolumn{2}{|c|}{$\begin{array}{c}\text { CICB3 after } \\
\text { experiment }(b)\end{array}$} \\
\hline Elemental line & $W t \%$ & Elemental line & $W t \%$ \\
\hline$C K$ & 0.00 & $C K$ & 0.59 \\
\hline$N K$ & 1.95 & $N K$ & 3.51 \\
\hline$O K$ & 52.14 & $O K$ & 65.14 \\
\hline$F K$ & 0.27 & $F K$ & 3.51 \\
\hline $\mathrm{NaK}$ & 0.46 & $\mathrm{NaK}$ & 0.00 \\
\hline$P K$ & 0.00 & $P K$ & 2.91 \\
\hline$P L$ & - & $P L$ & - \\
\hline $\mathrm{Cl} \mathrm{K}$ & 8.50 & $\mathrm{Cl} \mathrm{K}$ & 3.79 \\
\hline $\mathrm{Cl} \mathrm{L}$ & - & $C l L$ & - \\
\hline Ca K & 23.29 & Са K & 20.02 \\
\hline Ca L & - & Ca $L$ & - \\
\hline $\operatorname{ZrL}$ & 13.40 & $\mathrm{Cr} K$ & 0.53 \\
\hline $\operatorname{Zr} M$ & - & $C r L$ & - \\
\hline Total & 100.00 & Total & 100.00 \\
\hline
\end{tabular}

Table 3. Energy DisPersive SPectroscopy Analysis of (a) Cyanobacteria Immobilized Alginate Beads AND (B) Cyanobacteria ImMobilized Bead of CICB4 After the Treatment with Cr(VI)

CICB4 before CICB4 after
experiment $(a) \quad$ experiment $(b)$

\begin{tabular}{|c|c|c|c|}
\hline Elemental line & $W t \%$ & Elemental line & $W t \%$ \\
\hline$C K$ & 0.00 & $C K$ & 0.73 \\
\hline$N K$ & 0.00 & $N K$ & 3.99 \\
\hline$O K$ & 59.88 & $O K$ & 61.04 \\
\hline $\mathrm{NaK}$ & 0.45 & $F K$ & 0.00 \\
\hline$P K$ & 3.39 & $\mathrm{NaK}$ & 0.86 \\
\hline$P L$ & - & Si K & 4.75 \\
\hline$C l K$ & 13.91 & Si $L$ & - \\
\hline$C l L$ & - & $P K$ & 0.00 \\
\hline $\mathrm{Ca} \mathrm{K}$ & 22.19 & $P L$ & - \\
\hline Ca $L$ & - & $K K$ & 0.88 \\
\hline $\mathrm{Fe} \mathrm{K}$ & 0.18 & $K L$ & - \\
\hline $\mathrm{Fe} \mathrm{L}$ & - & Ca K & 17.16 \\
\hline \multirow[t]{5}{*}{ Total } & 100.00 & Ca L & - \\
\hline & & $\mathrm{Cr} K$ & 0.60 \\
\hline & & $\operatorname{Cr} L$ & - \\
\hline & & $\operatorname{ZrL}$ & 10.00 \\
\hline & & $\operatorname{ZrM}$ & 10000 \\
\hline & & Iotal & 100.00 \\
\hline
\end{tabular}


Table 4. Fourier Transform Infrared Analysis of (a) Blank Ca-Alginate Bead, (b) Algae Immobilized Alginate Beads, and (c) Algae Immobilized Bead of CICB3 After the Treatment with Cr(VI)

\begin{tabular}{|c|c|c|c|c|c|}
\hline \multicolumn{2}{|c|}{ CICB3 blank beads (a) } & \multicolumn{2}{|c|}{ CICB3 before experiment $(b)$} & \multicolumn{2}{|c|}{ CICB3 after experiment $(c)$} \\
\hline Frequency range & Functional groups & Frequency range & Functional groups & Frequency range & Functional groups \\
\hline 667 & $\mathrm{C}-\mathrm{S}, \mathrm{C}-\mathrm{O}-\mathrm{C}$ & 667 & $\mathrm{C}-\mathrm{S}, \mathrm{C}-\mathrm{OH}$ & 416 & $\mathrm{C}-\mathrm{N}-\mathrm{C}$ \\
\hline 1,047 & $\mathrm{C}-\mathrm{C}, \mathrm{C}-\mathrm{N}$ & 1,633 & $\mathrm{C}=\mathrm{O}, \mathrm{C}==\mathrm{C}$ & 1,038 & $\mathrm{P}-\mathrm{O}-\mathrm{C}, \mathrm{C}-\mathrm{C}$ \\
\hline 1,605 & N-H (Bend) & 2,358 & $-\mathrm{PH}$ & 1,420 & $\mathrm{C}-\mathrm{N},-\mathrm{OH}$ \\
\hline 2,367 & $-\mathrm{PH}$ & - & - & 1,596 & $\mathrm{COO}^{-}$ \\
\hline 3,742 & $-\mathrm{OH}$ & - & - & 3,399 & $-\mathrm{NH}_{2}$ \\
\hline
\end{tabular}

hydroxyls, indicating the presence of these groups on the biosorbent. The region $3,600-3,300 \mathrm{~cm}^{-1}$, next to the $\mathrm{O}-\mathrm{H}$ vibrations, showed the characteristic bands for $\mathrm{N}-\mathrm{H}$ stretching vibrations, present in algal biomass. Besides, several other functional groups were identified, such as $\mathrm{C}-\mathrm{H}$ bending of the aliphatic functional group $\left(2,924-2,854 \mathrm{~cm}^{-1}\right)$ and $\mathrm{C}-\mathrm{C}$ stretching vibrations of the aromatic ring $\left(1,419 \mathrm{~cm}^{-1}\right)$, while $\mathrm{C}-\mathrm{N}$ stretching of aromatics and $\mathrm{C}-\mathrm{O}$ stretching of alcohols and carboxylic acids were found in the region of $1,265-1,319 \mathrm{~cm}^{-1}$. In the region between 1,800 and $1,500 \mathrm{~cm}^{-1}$, the characteristic bands for proteins were seen, more specifically $\mathrm{C}=\mathrm{O}$ stretching vibrations of peptide bonds typical of amide-I bands and $\mathrm{N}-\mathrm{H}$ bending vibrations characteristic of amide-II bands. The strongest peak in this area was found at $1,604 \mathrm{~cm}^{-1}$, reflecting the amines and amides of algal biomass. On the contrary, the $\mathrm{C}-\mathrm{O}$ stretching vibrations of alcohols, carboxylic acids, and carbohydrate of polysaccharides of both algal biomass and alginate were noticed in the region between 1,026 and $1,087 \mathrm{~cm}^{-1}$. From the stability analysis, it has been found that the efficacies of the beads in removal of $\mathrm{Cr}(\mathrm{VI})$ has remained same up to 7 weeks. To measure the strength, five similar compression tests have been carried out and the average value of the breaking stress has been found as $0.2197 \mathrm{Mpa}$.

\section{Immobilization of $\mathrm{L}$. limneticus}

Effect of input factors on immobilization of cyanobacterial biomass onto calcium alginate bead

Effect of $\mathrm{pH}$ on immobilization. While concentrations of sodium alginate $(20 \mathrm{~g} / \mathrm{L})$, calcium chloride $(29.4 \mathrm{~g} / \mathrm{L})$, and algal biomass $(0.957 \mathrm{~g} / \mathrm{L})$ have been kept constant during immobilization of test strain, $\mathrm{pH}$ has been varied as 5, 7, 9, and 11 separately. The variation of removal of $\mathrm{Cr}(\mathrm{VI})$ using

F3 beads prepared at various $\mathrm{pH}$ condition is shown in Fig. 3. Removal of $\mathrm{Cr}(\mathrm{VI})$ has increased from $4.52 \% \pm 0.14 \%$ to
$18.52 \% \pm 0.57 \%$ with increase in $\mathrm{pH}$ from 5 to 9 . However, with further increase in $\mathrm{pH}$, there is a decrease in removal of $\mathrm{Cr}(\mathrm{VI})$. At $\mathrm{pH} 11$, removal obtained is only $13.35 \% \pm 0.41 \%$. Therefore, optimum $\mathrm{pH}$ for immobilization has been found to be 9 . With the increase in $\mathrm{pH}$ from 5 to 9 , there is increase in adsorption of metal ions per unit weight of biosorbent. When the $\mathrm{pH}$ of the medium is in acidic range, there is an adverse effect on biosorption capacity. For further increase in $\mathrm{pH}$ up to 11 , the removal is comparatively low. The reason behind the phenomena may be less availability of $\mathrm{Cr}(\mathrm{VI})$ in the solution due to the formation of complex compound in presence of other anion group (Sen et al., 2017).

Effect of $\mathrm{pH}$ on removal of mercury, cadmium, and lead was studied by Bayramoğlu et al. (2006). According to their study, the dependency of metal biosorption on $\mathrm{pH}$ is associated with both the functional groups present in the cell wall of the biosorbent and the chemistry of the metals in solution. The ionization state of the different functional group and the solubility of the metals strongly depend on the solution $\mathrm{pH}$. The negatively charged carboxylate and phosphate ions allow the microbial cells to bind cations. The maximum biosorption capacity was found in between the $\mathrm{pH}$ of 5 and 6 (Bayramoğlu et al., 2006). In another study Feng and Aldrich (2004) showed that the optimum $\mathrm{pH}$ for the removal of $\mathrm{Cu}$ (II) and $\mathrm{Pb}(\mathrm{II})$ is in the range of 5.8-8.5.

Effect of concentration of sodium alginate on immobilization. Concentration of sodium alginate was maintained at 20, 30, and $40 \mathrm{~g} / \mathrm{L}$, keeping other immobilization parameters such as concentrations of calcium chloride, algal biomass, and $\mathrm{pH}$ constant at $29.4 \mathrm{~g} / \mathrm{L}, 0.957 \mathrm{~g} / \mathrm{L}$, and 9, respectively. The beads have been tested for $\mathrm{Cr}(\mathrm{VI})$ removal. The removal is strongly dependent on sodium-alginate concentration. The removal decreases from $18.52 \% \pm 0.57 \%$ to $2.25 \% \pm 0.11 \%$, when sodium-alginate concentration increases from 20 to $40 \mathrm{~g} / \mathrm{L}$. At $30 \mathrm{~g} / \mathrm{L}$ sodium alginate concentration, the removal is minimum $(1.98 \% \pm 0.06 \%)$. Therefore, $20 \mathrm{~g} / \mathrm{L}$ has been

Table 5. Fourier Transform Infrared Analysis of (a) Blank Ca-Alginate Bead, (B) Algae Immobilized Alginate Beads, and (c) Algae Immobilized Bead of CICB4 After the Treatment with Cr(VI)

\begin{tabular}{|c|c|c|c|c|c|}
\hline \multicolumn{2}{|c|}{ CICB4 blank beads (a) } & \multicolumn{2}{|c|}{ CICB4 before experiment ( $b$ ) } & \multicolumn{2}{|c|}{ CICB4 after experiment $(c)$} \\
\hline Frequency range & Functional groups & Frequency range & Functional groups & Frequency range & Functional groups \\
\hline 1,020 & $\mathrm{C}-\mathrm{C}$ & 462 & $\mathrm{C}-\mathrm{N}-\mathrm{C}$ & 667 & C-S \\
\hline 1,420 & $\mathrm{C}-\mathrm{N},-\mathrm{OH}$ & 1,038 & $\mathrm{P}-\mathrm{O}-\mathrm{C}$ & 1,038 & P-O-P, C-N \\
\hline 1,596 & $\mathrm{NH}_{2}$ & 1,438 & $-\mathrm{OH}$ & 1,429 & $-\mathrm{OH}$ \\
\hline 2,367 & $-\mathrm{PH}$ & 1,605 & $\mathrm{COO}^{-}$ & 1,652 & $\mathrm{C}=\mathrm{O}$ \\
\hline 3,296 & $\mathrm{~N}-\mathrm{H}$ & 2,925 & $-\mathrm{CH}_{3}-\mathrm{CH}_{2}$ & 2,367 & $-\mathrm{PH}$ \\
\hline - & - & 3,389 & $-\mathrm{NH}_{2}$ & 3,436 & $-\mathrm{NH}_{2}$ \\
\hline
\end{tabular}




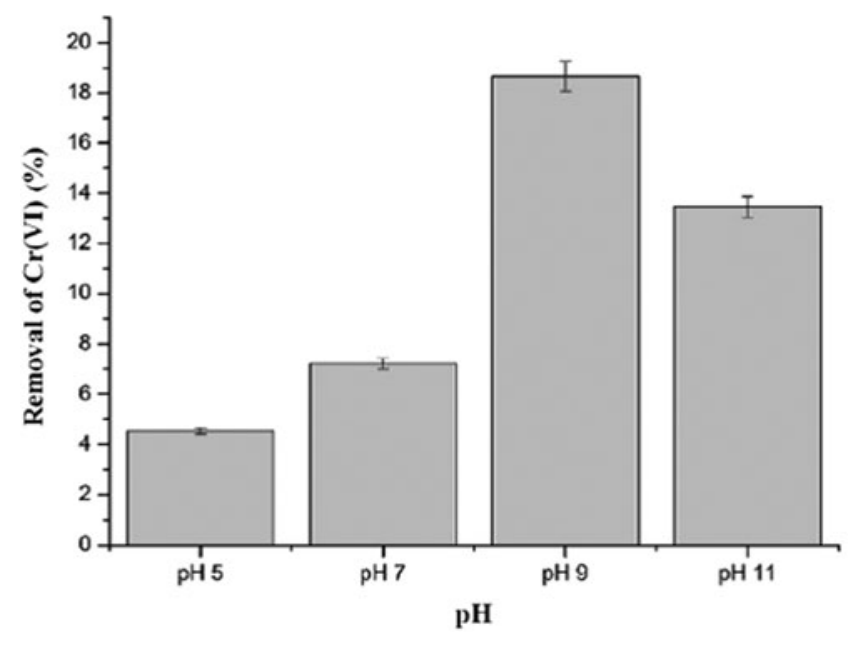

FIG. 3. The variation of removal of $\mathrm{Cr}(\mathrm{VI})$ for different $\mathrm{pH}$.

taken as optimum concentration of sodium alginate. This may be due to the adverse effect of higher concentration of sodium alginate during preparation of calcium alginate bead.

Effect of concentration of calcium chloride on immobilization. Concentration of calcium chloride was varied as 14.7, 29.4 , and $44.1 \mathrm{~g} / \mathrm{L}$, keeping other immobilization parameters such as concentrations of sodium alginate, algal biomass, and $\mathrm{pH}$ constant at $20 \mathrm{~g} / \mathrm{L}, 0.957 \mathrm{~g} / \mathrm{L}$, and 9 , respectively. To examine $\mathrm{Cr}(\mathrm{VI})$ removal efficacy, the same method has been followed as described above and it is seen that calcium chloride concentration has prominent effect on the removal of $\mathrm{Cr}(\mathrm{VI})$. The removal increases from $14.15 \% \pm 0.44 \%$ to $18.52 \% \pm 0.57 \%$ when calcium chloride concentration increases from 14.7 to $29.4 \mathrm{~g} / \mathrm{L}$. However, further increase in calcium chloride concentration results in decrease in removal of $\mathrm{Cr}(\mathrm{VI})$. At $44.1 \mathrm{~g} / \mathrm{L}$ calcium chloride, removal obtained is only $7.36 \% \pm 0.23 \%$. Therefore, $29.4 \mathrm{~g} / \mathrm{L}$ has been taken as optimum concentration of calcium chloride.

Effect of concentration of cyanobacterial biomass on immobilization. Concentration of algal biomass has been varied as $0.957,1.914$, and $2.871 \mathrm{~g} / \mathrm{L}$, keeping other immobilization parameters such as concentrations of sodium alginate, calcium chloride, and $\mathrm{pH}$ constant at $20 \mathrm{~g} / \mathrm{L}, 29.4 \mathrm{~g} / \mathrm{L}$, and 9 , respectively. It is observed that algal biomass concentration has pronounced effect on removal of $\mathrm{Cr}(\mathrm{VI})$. The removal increases from $18.52 \% \pm 0.57 \%$ to $19.43 \% \pm 0.53 \%$ and then to $20.52 \% \pm 0.64 \%$ when algal biomass concentration varies as $0.957,1.914$, and $2.871 \mathrm{~g} / \mathrm{L}$. More the cyanobacterial biomass, the more will be the functional groups as present in cell wall, and hence, more will be the removal of $\mathrm{Cr}(\mathrm{VI})$. Therefore, the optimum condition for immobilization by varying one parameter at a time has been found to be $\mathrm{CaCl}_{2} \cdot 2 \mathrm{H}_{2} \mathrm{O}: 29.4 \mathrm{~g} / \mathrm{L}$, sodium alginate: $20 \mathrm{~g} / \mathrm{L}$, cyanobacterial biomass: $2.871 \mathrm{~g} / \mathrm{L}$, and $\mathrm{pH}$ : 9 . Sample obtained at optimum condition is termed as CICB1. The removal of $\mathrm{Cr}(\mathrm{VI})$ obtained using $C I C B 1$ is $20.92 \pm 0.72 \%$. Similar experiment on increasing metal removal process with the increase in biomass dosage was reported by Chhikara and Dhankhar (2008). They studied biosorption of Cr(VI) using immobilized Aspergillus niger for different amount of biomass dosage ranging from 0.1 to $1.2 \mathrm{~g}$. The study revealed that up to $1 \mathrm{~g}$ biomass dosage, the uptake of $\mathrm{Cr}(\mathrm{VI})$ increased significantly and beyond that, the removal became stationary. Thus, $1 \mathrm{~g}$ was chosen as optimum dosage.

\section{Variation of removal of $\mathrm{Cr}(\mathrm{VI})$ with time for different IC}

The comparative study on removal of $\mathrm{Cr}(\mathrm{VI})$ between $C I C B 2, C I C B 3$, and $C I C B 4$ indicates that the removal is maximum $(89.8 \% \pm 2.81 \%)$ for $C I C B 2$ in comparison with CICB3 $(44.82 \% \pm 1.40 \%)$ and CICB4 $(48.89 \% \pm 1.52 \%)$. This is because in the case of $C I C B 2$, higher amount of algal biomass $(7 \mathrm{~g} / \mathrm{L})$ was used in comparison with the other two beads. More the algal biomass, the more is the availability of binding site and possibility of binding. However, between $C I C B 3$ and $C I C B 4, C I C B 4$ gives more removal. This may be due to the presence of more amount of BG-11 medium in CICB4. Although $C I C B 2$ shows higher removal in comparison to the other two beads, from the economic point of view, it is better to use $C I C B 3$ and $C I C B 4$, as these two beads require lower cyanobacterial dosage. Thus, in the present study, these two beads (CICB3 and $C I C B 4$ ) have been chosen for further analysis.

Further, to examine the efficacy of $C I C B$, removal of $\mathrm{Cr}(\mathrm{VI})$ using only alginate beads (abiotic control) and free cyanobacterial strain without immobilization (biotic control) have been investigated. From the experiment, it has been observed that $0.53 \% \pm 0.002 \%, 0.72 \% \pm 0.002 \%$, and $0.73 \% \pm 0.001 \% \mathrm{Cr}(\mathrm{VI})$ have been removed using blank alginate beads with $5 \mathrm{mg} / \mathrm{L}$ initial $\mathrm{Cr}(\mathrm{VI})$ concentration after 4,8 , and 12 days, respectively, whereas under identical operating conditions, free cyanobacterial strain without immobilization can remove $21.02 \% \pm 0.032 \%, 37.23 \% \pm$ $0.43 \%$, and $43.11 \% \pm 0.083 \% \mathrm{Cr}(\mathrm{VI})$ from the solution for same period of time. However, in the current study, 39.22\% \pm $1.063 \%, 56.03 \% \pm 2.085 \%$, and $60.77 \% \pm 2.082 \% \mathrm{Cr}(\mathrm{VI})$ were removed using CICB3 and $44.76 \% \pm 1.013 \%, 64.35 \% \pm$ $2.023 \%$, and $82.81 \% \pm 3.051 \% \mathrm{Cr}(\mathrm{VI})$ were removed using CICB4 under the same operating condition.

The variation of removal with time for different ICs using CICB3 has been shown in Fig. 4a. From Fig. $4 \mathrm{a}$, it is seen that $4 \mathrm{~F} 4$ with increase in IC from 5 to $15 \mathrm{mg} / \mathrm{L}$, the removal decreases from $75.63 \% \pm 2.36 \%$ to $41.78 \% \pm 1.30 \%$ for 20 days of operation. This suggests that removal process is not diffusion controlled, but kinetically controlled. Maximum removal of $75.63 \% \pm 2.36 \%$ is obtained with $5 \mathrm{mg} / \mathrm{L}$ IC. The rate of removal is more for initial 4 days and after that, the removal becomes almost constant. The variation of removal with time for different ICs for CICB4 has been shown in Fig. $4 \mathrm{~b}$. From Fig. 4b, it is seen that removal increases with decrease in concentration. When IC increases from 5 to $15 \mathrm{mg} / \mathrm{L}$, removal of $\mathrm{Cr}(\mathrm{VI})$ decreases from $85.78 \% \pm 2.66 \%$ to $55.98 \% \pm 1.13 \%$ for 20 days of operation. This suggests that bulk diffusion resistance is negligible for the system. As the removal of $\mathrm{Cr}(\mathrm{VI})$ is significantly affected with the varying IC, it can be stated that, for this system, the resistance due to kinetic parameter plays the dominant role, and by altering such kinetic parameter, the rate of reaction can be controlled. Thus, the removal process is not diffusion controlled, but kinetically controlled (Treybal, 1980). However, higher removal at lower concentration of $\mathrm{Cr}(\mathrm{VI})$ may be due to the presence of sufficient amount of immobilized bioremediant $(100 \mathrm{~g} / \mathrm{L}$ in each case $)$ and when the IC increases, the ratio of the sorptive surface to the $\mathrm{Cr}(\mathrm{VI})$ ion concentration becomes 

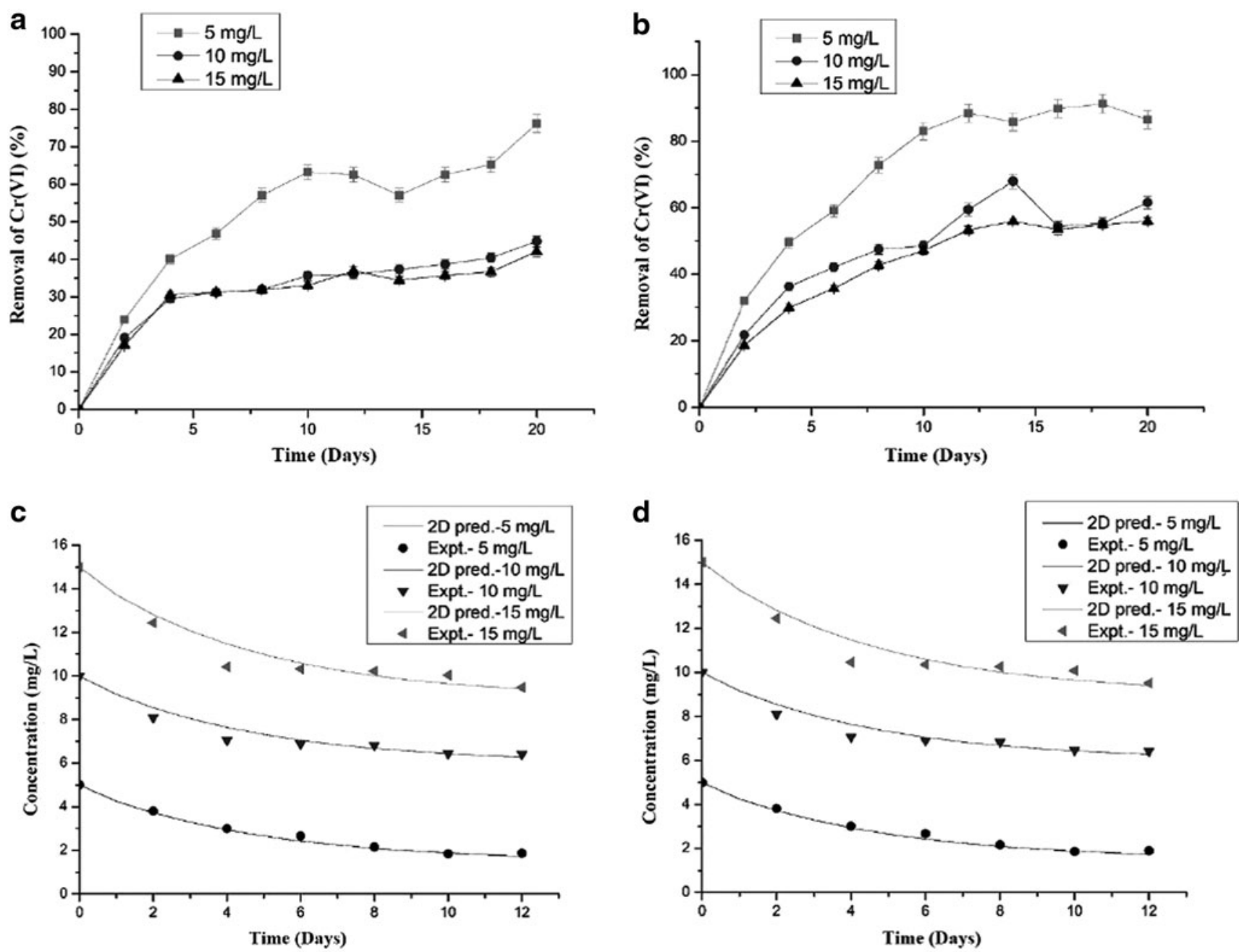

FIG. 4. (a) The variation of removal with time for different initial concentration of $\mathrm{Cr}(\mathrm{VI})$ using CICB3. (b) The variation of removal with time for different initial concentration of $\mathrm{Cr}(\mathrm{VI})$ using CICB4.. (c) The experimental and model predicted results of removal of $\mathrm{Cr}(\mathrm{VI})$ for different initial concentration of $\mathrm{Cr}(\mathrm{VI})$ for $C I C B 3$. (d) The experimental and model predicted results of removal of $\mathrm{Cr}(\mathrm{VI})$ for different initial concentration of $\mathrm{Cr}(\mathrm{VI})$ for CICB4.

less, which results in a decrease in removal (Chhikara and Dhankhar, 2008). Chhikara and Dhankhar (2008) showed that with the increase in $\mathrm{Cr}(\mathrm{VI})$ concentration up to $100 \mathrm{mg} / \mathrm{L}$, the removal gradually decreased, and after that, there was a sharp decrease in removal. Further, it was seen that the initial rate of $\mathrm{Cr}(\mathrm{VI})$ removal is high up to 4 days of operation. The rate became slow after 4 days and the removal became almost invariant with time. The biosorption is a fast process, and thus, initially biosorption is the only mechanism for metal removal. For biosorption, surface molecules can have a saturation level, after which no more metallic ions can be adsorbed. During bioaccumulation, the metal ions get inside the cell cytoplasm by some metabolism leaving biosorption site vacant. For accumulation of metal, an efflux mechanism can be functioning at a certain metal concentration preventing accumulation of more metal (Velasquez and Dussan, 2009). For lower IC, biosorption as well as bioaccumulation may be taking place, whereas for higher IC of 10 and $15 \mathrm{mg} / \mathrm{L}$, the active sites of cell have been occupied by metal ions through biosorption, and since bioaccumulation is slow process, it may not happen so quickly, and thus, removal becomes invariant with time. Therefore, the constant removal after 12 days may be attributed to the continuous biosorption and desorption processes by immobilized microalgae with $\mathrm{Cr}(\mathrm{VI})$.

It has been observed from the statistical analysis that for CICB3, there is no significant difference between the mean values of percentage removal with increase in time since $p>0.05$, and there is a difference between the values of percentage removal with increase in concentration of chromium from 5 to $15 \mathrm{mg} / \mathrm{L}(p<0.05)$. However, for $C I C B 4$, statistical analysis results reveal that there is no significant difference between the values of percentage removal from days 0 to 10 ; but there is a significant difference between days 0 and 12 and later on $(p<0.05)$. Also, it has been seen that there is a significant difference between the mean values of percentage removal with increase in IC of chromium from 5 to $15 \mathrm{mg} / \mathrm{L}$.

\section{Mathematical modeling}

Optimization of model parameters. In this study, only one equation of transient diffusive mass transport equation is considered. The equation is nonlinear with two unknown parameters, diffusivity $\left(D^{*}\right)$, and biosorption capacity $\left(k_{a d}\right)$ of $\mathrm{Cr}(\mathrm{VI})$. So, the practical situation cannot be solved 
easily. Regression method is considered with practical knowledge of diffusivity of the component in liquid medium in the range of $10^{-9} \mathrm{~m}^{2} / \mathrm{s}$. During the process of solving, transport of diluted species is considered, within which the backward differentiation formula (BDF) solver, an implicit solver, is used with an absolute concentration tolerance $10^{-5}$ $\mathrm{mg} / \mathrm{L}$ to study the concentration profile of $\mathrm{Cr}(\mathrm{VI})$. After so many iterations by changing the values of $D^{*}$ and $k_{a d}$, the reasonable values have come out and these are $3 \times 10^{-9} \mathrm{~m}^{2} / \mathrm{s}$ and $1.494 \mathrm{~m} / \mathrm{s}$, respectively.

Model validation. The values of $D^{*}\left(3 \times 10^{-9} \mathrm{~m}^{2} / \mathrm{s}\right)$ and $k_{a d}(1.494 \mathrm{~m} / \mathrm{s})$, obtained through a trial and error method, were used to solve Equation (3) to get concentration profile with time for both CICB3 and CICB4. The experimentally observed and model predicted concentration-time histories of $\mathrm{Cr}(\mathrm{VI})$ for solution of different IC in the range of $5-15 \mathrm{mg} / \mathrm{L}$ are represented in Fig. $4 \mathrm{c}$ and d, when treated with $C I C B 3$ and $C I C B 4$, respectively. From Fig. $4 \mathrm{c}$, it is seen that the simulated data match well with experimental ones with average relative deviation of $3.54 \%, 2.97 \%$, and $3.19 \%$ for solution of 5,10 , and $15 \mathrm{mg} / \mathrm{L}$, respectively. Similarly, from Fig. 4d, average relative deviation of $3.84 \%, 3.01 \%$, and $3.22 \%$ reconfirms the suitability of the model to predict the concentration profile with time for $\mathrm{Cr}(\mathrm{VI})$ solution of 5,10 , and $15 \mathrm{mg} / \mathrm{L}$, respectively.

For developing the model, few assumptions were considered. These assumptions, on the contrary, can be thought as limitations of the modeling. They are listed as follows:

(a) The experimental results are validated with the model prediction at different ICs, while the concentration distribution of $\mathrm{Cr}(\mathrm{VI})$ at different space of the biosorption reactor has not been addressed.

(b) The L. limneticus strain was immobilized in calcium alginate bead (polymeric matrix) and was kept at the bottom inside the conical flask, considered as batch reactor for removal of $\mathrm{Cr}(\mathrm{VI})$. The bed size may not remain constant throughout the reaction time due to the minute enlargement of the alginate beads. However, to simplify the model, the adsorbent bed was assumed to remain same as a bunch of particles having equal size with uniform porosity during the reaction time.

(c) Hydrodynamic model prediction makes an important role for optimization of process parameter and designing a biosorption reactor in cost-effective way. This study was not incorporated here.

(d) Further, no convective mass transfer has been assumed in the system. Only mass transport resistance and biosorption resistance are present. Biosorption resistance was the dominant factor in this model.

\section{Conclusion}

The effectiveness of alginate immobilized $L$. limneticus in remediation of $\mathrm{Cr}(\mathrm{VI})$ has been assessed. Four different methods were followed for immobilization. Input variables such as $\mathrm{pH}$, concentrations of sodium alginate, calcium chloride, and cyanobacterial dose have significant effect on the efficacy of bead in removal of $\mathrm{Cr}(\mathrm{VI})$. The maximum dose of cyanobacterial biomass was used in preparation of $C I C B 2$ and it showed maximum removal efficacy. EDS study con- firms the existence of $\mathrm{Cr}(\mathrm{VI})$ in the alginate immobilized biomass after treatment with $\mathrm{Cr}(\mathrm{VI})$ laden wastewater. Removal of $\mathrm{Cr}(\mathrm{VI})$ was seen inversely related with IC when $C I C B 3$ and CICB4 were used as bioremediant. Two types of mass transport, molecular or diffusive transport and convective transport, were discussed using CFD model. The predominance of molecular or diffusive transport over convective transport was observed. The simulated data matched quite well with experimental ones. Thus, it can be stated that alginate immobilized $L$. limneticus can effectively be used for $\mathrm{Cr}(\mathrm{VI})$ removal. However, based on the cited work in the literature and recent articles, the present study has envisaged the following scope for future work in the context of abatement of $\mathrm{Cr}(\mathrm{VI})$, such as (1) finding out suitability and feasibility of using the present microalgal strains for removal of $\mathrm{Cr}(\mathrm{VI})$ from real industrial wastewater; (2) implementation of the test strains for removal of $\mathrm{Cr}(\mathrm{VI})$ in a continuous flow reactor; (3) scaling-up of reactor suitable for industrial use; (4) prediction of the concentration distribution of $\mathrm{Cr}(\mathrm{VI})$ at different space of the biosorption reactor using mathematical model; and finally, (5) exploration of different immobilization matrix in place of alginate only.

\section{Nomenclature}

$C^{*}=$ concentration at any time $(\mathrm{mg} / \mathrm{L})$

$C_{e}=$ equilibrium concentration $(\mathrm{mg} / \mathrm{L})$

$D^{*}=$ diffusivity of chromium element within the solution $\left(\mathrm{m}^{2} / \mathrm{s}\right)$

$k_{a d}=$ rate constant $\left(\right.$ second $\left.^{-1}\right)$

$S=$ generation term

$t=$ contact time (days)

$U^{*}=$ convective velocity $(\mathrm{m} / \mathrm{s})$

\section{Author Disclosure Statement}

No competing financial interests exist.

\section{Funding Information}

Authors are grateful to National Institute of Technology Durgapur, Durgapur, India for providing financial support for the research activities.

\section{Supplementary Material}

Supplementary Figure S1

\section{References}

Ahalya, N., Ramachandra, T.V., and Kanamadi, R.D. (2003). Biosorption of heavy metals. Res. J. Chem. Environ. 7, 71.

Ahluwalia, S.S., and Goyal, D. (2007). Microbial and plant derived biomass for removal of heavy metals from wastewater. Bioresour. Technol. 98, 2243.

Anjana, K., Kaushik, A., Kiran, B., and Nisha, R. (2007). Biosorption of $\mathrm{Cr}(\mathrm{VI})$ by immobilized biomass of two indigenous strains of cyanobacteria isolated from metal contaminated soil. J. Hazard. Mater. 148, 383.

Baltrènaite, E., Lietuvninkas, A., and Baltrènas, P. (2018). Biogeochemical and engineered barriers for preventing spread of contaminants. Environ. Sci. Poll. Res. 25, 5254.

Baltrènas, P., Baltrènaite, E., Kleiza, J., and Švedienè, J. (2016). A biochar-based medium in the bio-filtration system: Removal 
efficiency, microorganism propagation and the medium penetration modeling. J. Air Waste Manage. Assoc. 66, 673.

Bayramoğlu, G., Tuzun, I., Celik, G., Yilmaz, M., and Arica, M.Y. (2006). Biosorption of mercury(II), cadmium(II) and lead(II) ions from aqueous system by microalgae Chlamydomonas reinhardtii immobilized in alginate beads. Int. J. Miner. Process. 81, 35.

Bhattacharyya, A., Dutta, S., De, P., Ray, P., and Basu, S. (2010). Removal of mercury(II) from aqueous solution using papain immobilized on alginate bead: Optimization of immobilization condition and modeling of removal study. Bioresour. Technol. 101, 9421.

Blanch, H.W., and Clark, D.S. (2007). Biochemical Engineering, special Indian ed. New York: Marcel Dekker.

Cataldo, S., Gianguzza, A., and Pettignano, A. (2016). Sorption of $\mathrm{Pd}(\mathrm{II})$ ion by calcium alginate gel beads at different chloride concentrations and $\mathrm{pH}$. A kinetic and equilibrium study. Arab. J. Chem. 9, 656.

Chatterjee, S., Dutta, S., Mukherjee, M., Ray, P., and Basu, S. (2015). Studies on removal of lead(II) by alginate immobilized bromelain (AIB). Desalin. Water Treat. 56, 409.

Chhikara, S., and Dhankhar, R. (2008). Biosorption of Cr(VI) ions from electroplating industrial effluent using immobilized Aspergillus niger biomass. J. Environ. Biol. 29, 773.

De-Bashan, L.E., and Bashan, Y. (2010). Immobilized microalgae for removing pollutants: Review of practical aspects. Bioresour. Technol. 101, 1611.

Dutta, A., Zhou, L., Castillo, A., Carlos, O., and De Herdt, E. (2016). Cadmium(II), lead(II), and copper(II) biosorption on baker's yeast (Saccharomyces cerevesiae). J. Environ. Engg. 142, C6015002.

AU13 Eroglu, E., Smith, S.M., and Raston, C.L. (2015). Application of various immobilization techniques for algal bioprocesses. In Biomass and Biofuels from Microalgae. Cham: Springer.

Feng, D., and Aldrich, C. (2004). Adsorption of heavy metals by biomaterials derived from the marine alga Ecklonia maxima. Hydrometallurgy 73, 1.

Gad, S.C. (1989). Acute and chronic systemic chromium toxicity. Sci. Total Environ. 86, 149.

Glaser, B., Baltrènas, P., Kammann, C., Kern, J., and Baltrènaite, E. (2017). Editorial: Special issue on biochar as an option for sustainable resource management (EU COST Action TD1107 final publication). J. Environ. Eng. Landsc. 25, 83.

Gupta, V.K., and Rastogi, A. (2009). Biosorption of hexavalent chromium by raw and acid-treated green alga Oedogonium hatei from aqueous solutions. J. Hazard. Mater. 163, 396.

Hu, L., Liu, Y., Zeng, G., Chen, G., Wan, J., Zeng, Y., Wang, L., Wu, H., Xu, P., Zhang, C., and Cheng, M. (2017). Organic matters removal from landfill leachate by immobilized Phanerochaetech rysosporium loaded with graphitic carbon nitride under visible light irradiation. Chemosphere 184, 1071.

Hu, L., Zeng, G., Chen, G., Dong, H., Liu, Y., Wan, J., Chen, A., Guo, Z., Yan, M., Wu, H., and Yu, Z. (2016). Treatment of landfill leachate using immobilized Phanerochaetech rysosporium loaded with nitrogen-doped $\mathrm{TiO}_{2}$ nanoparticles. J. Hazard. Mater. 301, 106.

Hu, L., Zhong, H., and He, Z. (2019). The cytotoxicities in prokaryote and eukaryote varied for $\mathrm{CdSe}$ and $\mathrm{CdSe} / \mathrm{ZnS}$ quantum dots and differed from cadmium ions. Ecotoxicol. Environ. Saf. 181, 336.

Kumar, K.S., Dahms, H.U., Won, E.J., Lee, J.S., and Shin, K.H. (2015). Microalgae - A promising tool for heavy metal remediation. Ecotoxicol. Environ. Saf. 113, 329.

Kumar, K.K., Prasad, M.K., Sarma, G.V.S., and Murthy, C.V.R. (2009). Removal of $\mathrm{Cd}(\mathrm{II})$ from aqueous solution using immobilized Rhizomucor tauricus. J. Microbial. Biochem. Technol. 1, 015.

Kundu, N., Pal, M., and Saha, S. (2008 July). East Kolkata 4 AU14 Wetlands: A resource recovery system through productive activities. In Proceedings of Taal 2007: The 12th World Lake Conference. p. 868.

Ma, Y., Zhong, H., and He, Z. (2019). Cr(VI) reductase activity locates in the cytoplasm of Aeribacillus pallidus BK1, a novel $\mathrm{Cr}(\mathrm{VI})$-reducing thermophile isolated from Tengchong geothermal region, China. Chem. Eng. J. 371, 524.

Markou, G., and Nerantzis, E. (2013). Microalgae for high-value compounds and biofuels, production: A review with focus on cultivation under stress conditions. Biotechnol. Adv. 31, 1532.

Migahed, F., Abdelrazak, A., and Fawzy, G. (2017). Batch and continuous removal of heavy metals from industrial effluents using microbial consortia. Int. J. Environ. Sci. Technol. 14, 1169.

Mukherjee, K., Saha, R., Ghosh, A., and Saha, B. (2013). Chromium removal technologies. Res. Chem. Intermed. 39, 2267.

Ontañon, O.M., González, P.S., Barros, G.G., and Agostini, E. (2017). Improvement of simultaneous $\mathrm{Cr}(\mathrm{VI})$ and phenol removal by an immobilised bacterial consortium and characterisation of biodegradation products. New Biotechnol. 37, 172.

Papageorgiou, S.K., Kouvelos, E.P., and Katsaros, F.K. (2008). Calcium alginate beads from Laminaria digitata for the removal of $\mathrm{Cu}^{+2}$ and $\mathrm{Cd}^{+2}$ from dilute aqueous metal solutions. Desalination 224, 293.

Petrovič, A., and Simonič, M. (2015). The effect of carbon source on nitrate and ammonium removal from drinking water by immobilised Chlorella sorokiniana. Int. J. Environ. Sci. Technol. 12, 3175.

Prabhakaran, D.C., Bolaños-Benitez, V., Sivry, Y., Gelabert, A., Riotte, J., and Subramanian, S. (2019). Mechanistic studies on the bioremediation of $\mathrm{Cr}(\mathrm{VI})$ using Sphingopyxis macrogoltabida SUK2c, a Cr(VI) tolerant bacterial isolate. Biochem. Eng. J. 150, 107292.

Sen, S., Dutta, S., Guhathakurata, S., Chakrabarty, J., Nandi, S., and Dutta, A. (2017). Removal of Cr(VI) using a cyanobacterial consortium and assessment of biofuel production. Int. Biodeter. Biodegrad. 119, 211.

Sen, G., Sen, S., Thakurta, S.G., Chakrabarty, J., and Dutta, S. (2018). Bioremediation of $\mathrm{Cr}(\mathrm{VI})$ using live cyanobacteria: experimentation and kinetic modelling. J. Environ. Eng. 144, 04018089.

Shuler, M.L., and Kargi, F. (2008). Bioprocess Engineering. New Delhi: Prentice-Hall of India.

Szekalska, M., Puciłowska, A., Szymańska, E., Ciosek, P., and Winnicka, K. (2016). Alginate: Current use and future perspectives in pharmaceutical and biomedical applications. Int. J. Polym. Sci. 2016.

Treybal, R.E. (1980). Mass Transfer Operations. New York.

Upendar, G., Singh, S., Chakrabarty, J., Ghanta, K.C., Dutta, S., and Dutta, A. (2018). Sequestration of carbon dioxide and production of biomolecules using cyanobacteria. J. Environ. Manage. 218, 234.

Velasquez, L., and Dussan, J. (2009). Biosorption and bioaccumulation of heavy metals on dead and living biomass of Bacillus sphaericus. J. Hazard. Mater. 167, 713.

Wang, S., Vincent, T., Faur, C., and Guibal, E. (2016). Alginate and algal-based beads for the sorption of metal cations: $\mathrm{Cu}$ (II) and $\mathrm{Pb}$ (II). Int. J. Mol. Sci. 17, 1453.

Wang, S., Vincent, T., Roux, J.C., Faur, C., and Guibal, E. (2017). Pd(II) and Pt(IV) sorption using alginate and algalbased beads. Chem. Eng. J. 313, 567. 


\section{Supplementary Data}
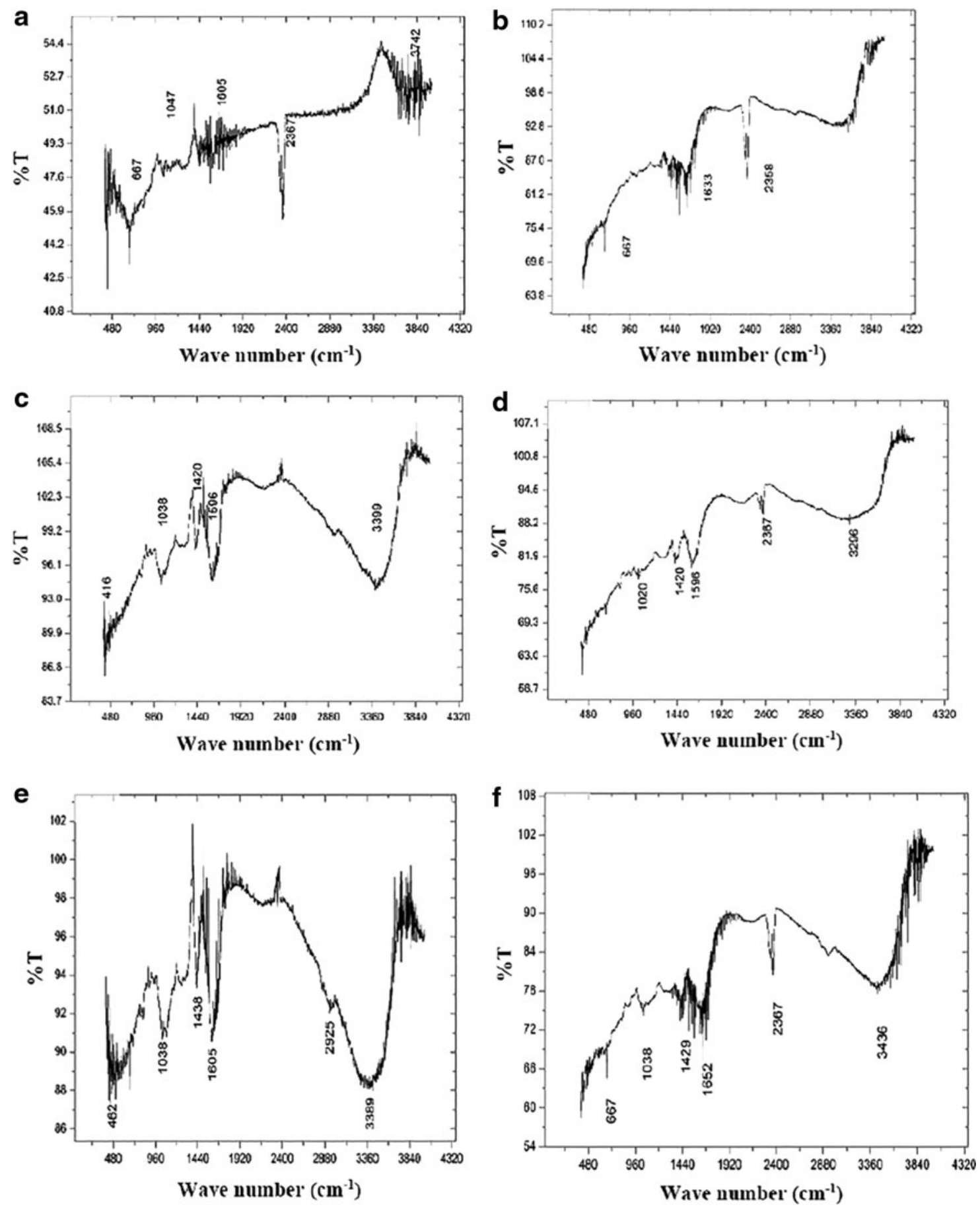

SUPPLEMENTARY FIG. S1. (a) FTIR image of blank Ca-alginate bead for CICB3. (b) FTIR image of $C I C B 3$ before treatment with $\mathrm{Cr}(\mathrm{VI})$. (c) FTIR image of $C I C B 3$ after treatment with $\mathrm{Cr}(\mathrm{VI})$. (d) FTIR image of blank Ca-alginate bead for CICB4. (e) FTIR image of CICB4 before treatment with Cr(VI). (f) FTIR image of CICB4 after treatment with Cr(VI). $C I C B$, cyanobacteria immobilized calcium alginate bead; FTIR, Fourier transform infrared. 


\section{AUTHOR QUERY FOR EES-2019-0035-VER9-SEN_1P}

AU1: Please note that gene symbols in any article should be formatted per the gene nomenclature. Thus, please make sure that gene symbols, if any in this article, are italicized.

AU2: Please indicate if any of the authors are AEESP members.

AU3: Please identify (highlight or circle) all authors' surnames for accurate indexing citations.

AU4: Please provide affiliation 2 in English as per journal style.

AU5: Please mention the department name for affiliation 3, if any.

AU6: Please confirm the address of correspondence.

AU7: Please confirm the hierarchy of heading levels.

AU8: The Publisher requests for readability that no paragraph exceeds 15 typeset lines. Please check for long paragraphs and divide where needed.

AU9: Reference "Allway and Ayres, 1997" is not listed in the reference list. Please provide the complete details in the reference list.

AU10: Please note that we have retained the "Nomenclature" section before "Author Disclosure Statement" section. Please check and confirm if this is OK.

AU11: Please confirm the accuracy of "Funding Information."

AU12: References "Bhattacharyya et al. (2010), Blanch and Clark (2007), Kundu et al. (2008), Shuler and Kargi (2008)" are not cited in the text. Please insert the citations in the text.

AU13: Please mention the editors' names and page range for the reference "Eroglu et al. (2015)."

AU14: Please mention the proceedings held location for the reference "Kundu et al. (2008)."

AU15: Please mention the publisher name for the reference "Treybal (1980)."

AU16: Please mention the significance of bold value in Table 2. 